\title{
Investment in Cashew Kernel Oil Production: Cost and Return Analysis of Three Processing Methods
}

\author{
Yahaya A.T. ${ }^{1, *}$, Taiwo O. ${ }^{1}$, Shittu T.R. ${ }^{1}$, Yahaya L.E. ${ }^{2}$, Jayeola C.O. ${ }^{2}$ \\ ${ }^{1}$ Economics and Statistics Unit, Cocoa Research Institute of Nigeria, PMB 5244, Ibadan \\ ${ }^{2}$ End Use Research Division, Cocoa Research Institute of Nigeria, PMB 5244, Ibadan
}

\begin{abstract}
Three methods of expressing cashew (Anacardium occidentale L) oil from kernel were investigated. The physicochemical characteristics of the resulting oils were assayed. Parameters characterized included refractive index, melting point, viscosity ratio, acid value, iodine number, peroxide value, saponification value etc. While there is no significant difference in the value for specific gravity, moisture content, refractive index, viscosity ratio, melting point; there are differences in value for chemical variables such as saponification value, iodine value and peroxide value. The highest yield value of $48.8 \%$ was recorded for soxhlet method of extraction. The high value of $10.12 \mathrm{meq} / \mathrm{kg}$ obtained for aqueous method can be rationalized on the basis that traces of water cannot be completely ruled out and this result to hydrolysis of the ester bond of the triglyceride. The Cost and return analysis of the three methods of expressing cashew kernel oil was also examined. The method of evaluation involved an investment decision model comprising Net present value (NPV), Benefit Cost Ratio (BCR) and Internal Rate of Return (IRR) quality parameters of the resulting oils were characterized. The investment profile revealed that all the methods were viable, however the soxhlet method has the highest NPV (N227, 727 at $21 \%$ and N328, 678 at $32 \%$ ) and BCR thus indicating its high returns on investment.
\end{abstract}

Keywords Cashew Kernel Oil, Investment, Benefit Cost Ratio, Cost Analysis

\section{Introduction}

The cashew tree (Anacardium occidentale $L$ ) is native to tropical America. The specie belongs to the class of the dicotyledons, order terebintals, family Anacardiaceae (1). There has been growing interest in cashew and this can be ascribed to the purported dual role of the kennel: it can be used as a substitute for peanut and almond in the confectionery industry and as an important source of lipids and protein.

The tree which is widely cultivated in Asia for its nuts and other products grows as tall as twelve meters with a thick and tortuous trunk and branches so winding that they frequently reach the ground. The cashew 'fruit' is very peculiar and is really not a fruit but a swollen pedicle that grow, behind the real fruit which yields, "the cashew $(2,3)$ ". This large pulpy and juicy part is a pseudo fruit with a true sweet flavor and aroma and the cashew nut grows externally in its own kidney shaped hard shell at the end of the pseudo fruit or pedicle which is commonly referred to as the cashew fruit or apple. The shell is $2-3 \mathrm{~m}$ thick, with a leathery outer case and a thinner, harder inner case, between which is a honey combs structure containing the phenolic cashew nut shell liquid

* Corresponding author:

ronke.yahaya@yahoo.com (Yahaya A.T.)

Published online at http://journal.sapub.org/economics

Copyright (C) 2012 Scientific \& Academic Publishing. All Rights Reserved
CNSL; an excellent source of phenol for polymer production $(4,14)$.

The kernel is protected from the latter both by the tough skin and the inner case, and is a rich source of protein, carbohydrate and the triglyceride, cashew kernel oil. The kernel and the shell liquid each comprise $20-25 \%$ of the nut which the remaining consists of the testa and the shell structure. Cashew kernel oil as a good source of vegetable oil has been recognized and this has found great use in domestic cooking and pharmaceutics (5). Cashew kernels are of high nutritive value. It contains 21 percent of protein, fat $(47 \%)$, moisture (5.9\%), carbohydrates $(22 \%)$, phosphorus $(0.45 \%)$, calcium $(0.05 \%)$, iron $(5 \%)$ for every $100 \mathrm{gm}$ and other mineral elements. Cashew kernel contains 47 percent fat but 82 percent of this is unsaturated fatty acid, which lowers the cholesterol level in blood. The most prominent vitamins in cashew are Vitamin A, D and E, which help to assimilate fats and increase the immunity level.

The cashew has a long record as a useful plant, but only in the twentieth century did it become an important tree crop (6). It has the potential to provide source of livelihood for the cashew growers, empower rural women in the processing sector, create employment opportunities and generate foreign exchange through exports.

Today, the crop is extensively cultivated for its nuts which are good source of vegetable oils, however, processing the kernel to obtain quality edible oil has always posed problem for oil processor. This work was therefore aimed at eluci- 
dating the effects of three different extraction methods on the quality of cashew kernel oil and their economic viability.

\section{Methodology}

Cashew nuts were obtained from the plot of Cocoa Research Institute of Nigeria, Ibadan. The kernels were isolated using a simple cutter. This was used to slit each nut open, and a knife employed to remove the kernel immediately from the shell to minimize contamination with the CNSL. The kernels were subjected to roasting at $70^{\circ} \mathrm{C}$ for 30 minutes and this ensures the removal of the testa. The kernels were then blended using an automated blender to obtain powdered sample.

\subsection{Soxhlet Extraction}

This employed the use of a soxhlet apparatus. The extraction was carried out according to standard procedures (7). In this case, $n$-hexane was used as the extracting solvent and this was carried out for 7-8 hours. At the end of the extraction, the oil was desolventized and the oil yield was determined based on the weight difference of the sample.

\subsection{Aqueous Extraction}

This was carried out in compliance with Fellow and Hampton (8). In a typical experiment, 1 part of the blended kernel was mixed with 4 parts of water and the mixture was boiled for 2 hours with intermittent stirring until all the oils are leached into the liquid phase. Then the oil interfacing with water was transferred into a separating funnel for separation. The process was repeated severally until the residue (meal) was oil free. The oil recovery was also determined based on the original weight of sample.

\subsection{Mechanical Extraction}

A known weight of the blended kernel was introduced into a hydraulic press system and oil was obtained through the pressure exerted on the powdered kernel by means of the press. The oil yield was also determined by weight difference method.

\subsection{Physicochemical Assay}

The physical and chemical characteristics of the oils expressed by the different methods were assayed as follows: The moisture content was determined by drying on a hot plate (British Standard, BS 684). The refractive index of the oils were determined at $20^{\circ} \mathrm{C}(\mathrm{BS}, 84,1985$ with an Abbe refractormeter; the specific gravity at $20^{\circ} \mathrm{C} \mathrm{(9)} \mathrm{by} \mathrm{the} \mathrm{British}$ Standard Institute, BSI. The acid value, free fatty acids, saponification value, iodine value (Wijs), peroxide value were determined using standard methods of the American Oil Chemist Society AOCS (1976) and AOAC (1970), while the viscosity was carried out using the Ubehlode viscometer according to IUPAC procedures.

\subsection{The Investment Decision Model}

\subsubsection{Net Present Value (NPV)}

The net present value is an important tool in making decision by an investor investing in the production of cashew kernel oil. In arriving at the NPV, the stream of discounted cost and benefit were used to obtain the net income for a year.

Following Gotsch and Burner, (10) model, if we define NI as the net income (or benefit) from one year of production of cashew kernel oil as expected in year $t$, then the net present value of the expected net income from production of cycle ( 500 bottles of cashew kernel oil per cycle x 12 cycles/year) of 1 year duration will amount to 6,000 bottles of $350 \mathrm{ml}$ cashew kernel oil will amount to:

$$
\mathrm{NPV}_{I, t}=\sum_{i=1}^{I} \frac{\mathrm{INC}_{i, t}}{(1+\mathrm{r})^{i}}
$$

$\mathrm{INC}_{i, t}$ is the expected net income of production in year $\mathrm{t}$ given as:

$$
\mathrm{INCt}=\sum_{i=1}^{I}(\mathrm{REV} i, t-\mathrm{TC} i, t)
$$

Where REVi,t is the expected revenue from the cashew kernel oil production in year $\mathrm{t}$

$\mathrm{TC}$ is the total cost of production in year $\mathrm{t}$

$r$ is the discount rate or the opportunity cost of capital and $t$ is the time period.

In arriving at a conclusion, the selection criterion is to accept the investment of cashew kernel oil production as technically and economically visible if the net present value is positive. However if NPV is negative it implies that the stream of discounted income or benefit (REVi,t) is less than the discounted cost $\left(\mathrm{TC}_{i, t}\right)$. The implication of this is that the revenues are insufficient to allow for the recovery of the investment.

\subsubsection{Benefit Cost Ratio (BCR)}

The investment Decision model also utilizes the Benefit cost Ratio (BCR). It is given as the ratio of the sum of discounted benefit to the sum of discounted cost. Thus for a cycle of 1 year duration, the benefit cost ratio can be represented by the formula:

$$
\mathrm{BCR}_{i, t}=\sum_{I=0}^{I} \frac{\mathrm{DREV}_{i, t}}{\mathrm{DTC}_{i, t}}
$$

Where $\mathrm{DREV}_{i, t}$ is discounted revenue from cashew kernel oil production in year $\mathrm{t}$

$\mathrm{DTC}_{i, t}$ is the discounted total cost of cashew kernel oil production in year $t$.

According to Gittinger, 1989, (13) the decision rule is that for an investment to be economically viable, the ratio must be greater than unity.

\section{Results and Discussion}

The physical and chemical characteristics of the oils ex- 
tracted by the different methods are shown in table 1 . It is evident that soxhlet extraction gave the highest oil recovery of $48.81 \%$. This value is more than that obtained from both the aqueous and mechanical method of extraction. The high value of soxhlet extraction over the others can be rationalized on the basis that solvent used for extraction infuses directly into the sample, thus helping to remove all the triglyceride in the sample, but this is not the case with the other 2 methods. This value compares well with what is obtained by other works, groundnut oil (44.9\%), sesame seed oil (46.9\%), and palm kernel oil 49\% (11).

The moisture content is frequently used as an index of stability. Value obtained for the different method, are relatively low, however, that of aqueous shows a relatively high value of $4-6 \%$. The observed high value could be as a result of the method of extraction. Traces of moisture in the oil cannot be completely ruled out, hence the relatively high value. The refractive index of the oil is widely used as criterion of identity and quality. The values for these methods are within limit for edible oils. $(1.465-1.470)$ and compares well with the results of other workers, for example the refractive index of coconut oil is 1.453 while that of walnut oil is $1.477(9)$.

A golden yellow colour was obtained for both the aqueous and soxhlet methods, but it is dark yellow for the mechanical method. The observed colour difference may be attributed to the degradation of the oil due to heat generated mechanically in the course of extraction,. This has also been reported by other worker (12) for rubber seed oil. The viscosity which is a measure of the resistance offered by the oil to flow shows that mechanical method of extraction gives oil of higher viscosity than the other 2 methods. Viscosity is also related to the molecular weight as well as the solid content of oil.

The specific gravity is commonly used in conjunction with other figures in assessing the purity of oil. The specific gravity of cashew kernel oil falls within the narrow range of $0.900-0.925$ for vegetable oils and is close to those of some well known edible oils like sesame, soya beans and corn oils of $0.16-0.921$ and cotton seed and sunflower oils of $0.916-$ $0.9180(9)$.

The melting point of fat/oil indicates their state at room temperature and is also related to their fatty acid composition.
The higher the level of unsaturation of the fatty acids in oils the higher the melting point. For this study, the melting point of the mechanically extracted oil gave the highest melting point value of $7^{\circ} \mathrm{C}-19^{\circ} \mathrm{C}$.

The value of the free fatty acid is also shown in the table. Although, refined oils are largely devoid of free fatty acids, but considerable amount of this constituent may be present in the crude oil and this in fact is an index of purity of the oil. The value in the table revealed high value for aqueous extracted oil $(2.607 \%)$. This is not surprising since trace of moisture cannot be completely ruled out; there is therefore the likelihood that the ester linkages of the triglyceride would become vulnerable to attack leading to the rupturing of the bond, thus hydrolysis.

Saponification value of oil is an index of average molecular weight of the triglyceride composition of the oil. Values above $200 \mathrm{mg} / \mathrm{KOH}$ indicate the presence of fatty acids of low or fairly low molecular weight, while values below $190 \mathrm{mg} / \mathrm{KOH}$ is an indication that high molecular weight fatty acid are present. As shown in the table, the value of saponification obtained for the three methods of extraction suggests that they contain high molecular weight fatty acids. This also suggests that cashew kernel oil has a large number of carboxylic acid functional group with which alkali may react to yield cleaning agent, thus making it a suitable raw material for soap making. Ojeh (5) reported similar value for Cashew Kernel Oil.

The iodine value which is a measure of the degree of unsaturation in oil gives valuable information about the drying property of the oil as well as the extent of adulteration of the oil. It is helpful in determining the ability of oil to be hardened through the process of hydrogenation. The value in table indicates that cashew kernel oils are non-drying oil. Previous worker (Ojeh (5) obtained similar value of $84.98 \mathrm{mg} / \mathrm{kg}$ for cashew kernel oil. The values obtained for this study are within standard limit for edible oils.

The peroxide value for soxhlet extracted oil was 4.087, while that of aqueous and mechanically extracted oil are 10.128 and $3.60 \mathrm{meq} / \mathrm{kg}$ respectively. It is evident that the aqueous extracted oil has high peroxide values, which is above the allowable level for edible oils and the implication is that the oil has undergone hydrolytic oxidation.

Table 1. Physical and chemical characteristics of Cashew Kernel Oil

\begin{tabular}{l|c|c|c}
\hline \multicolumn{1}{c|}{ Parameters } & Soxhlet & Aqueous & Mechanical \\
\hline Colour & Golden Yellow & Golden Yellow & Dark Yellow \\
\% yield & 48.81 & 29.41 & 33.81 \\
Moisture Content $(\%)$ & $2-2.5$ & $4-6$ & $2-3$ \\
Specific gravity $\left(\right.$ at $\left.20^{\circ}\right)$ & 0.903 & 0.920 & 0.916 \\
Melting Point $\left(0^{\circ} \mathrm{C}\right)$ & $16-17$ & $16-17$ & $17-19$ \\
Refractive index $\left(\right.$ at $\left.20^{\circ} \mathrm{C}\right)$ & 1.466 & 1.466 & 1.490 \\
Viscosity Ratio & 1.12 & 1.16 & 1.18 \\
Acid Value $(\mathrm{Mg} \mathrm{KOH}(\mathrm{g}))$ & 4.76 & 5.049 & 5.01 \\
Free Fatty acid $(\%$ oleic acid) & 2.4386 & 2.607 & 2.31 \\
Saponification value $(\mathrm{Mg} \mathrm{KOH} / \mathrm{g})$ & 159.9 & 165.49 & 178 \\
Peroxide Value $(\mathrm{Meq} / \mathrm{Kg})$ & 4.087 & 10128 & 3.16 \\
Iodine Value $(\mathrm{Meq} / \mathrm{Kg})$ & 87.63 & 93.047 & 85.46 \\
\hline
\end{tabular}


Table 2. Investment profile for cashew oil production by Mechanical method

\begin{tabular}{|c|c|c|c|c|c|c|c|c|c|}
\hline Year & Cost $(\mathrm{N})$ & Revenue & $\begin{array}{c}\text { Increm. } \\
\text { Benf. }\end{array}$ & Disc. cost & Disc.benf. & $\begin{array}{c}21 \% \\
\text { factor }\end{array}$ & $\begin{array}{c}32 \% \\
\text { factor }\end{array}$ & $\begin{array}{c}\text { (NPV } \\
(21 \%)\end{array}$ & $\begin{array}{c}\text { NPV } \\
(32 \%)\end{array}$ \\
\hline 0 & 197,000 & - & $(197,000)$ & 197,000 & $(197,000)$ & 1 & 1 & $(197,000)$ & $(197,000)$ \\
\hline 1 & $2,077,026$ & $2,409,750$ & 332,724 & $1,715,623.5$ & $1,990,453.5$ & 0.827 & 0.758 & 274,830 & 253,205 \\
\hline 2 & $2,330,423.2$ & $2,536,237.5$ & $199,814.3$ & $1,591,671$ & $1,728,152.2$ & 0.683 & 0.574 & $136,473.2$ & 114,693 \\
\hline 3 & $2,614,734.8$ & $2,656,749.4$ & $42,014.6$ & $1,474,710.6$ & $1,498,406.7$ & 0.564 & 0.435 & $23,696.23$ & $18,276.4$ \\
\hline 4 & $2,933,732.4$ & $2,789,586.9$ & $(144,145.5)$ & $1,370,053$ & $1,302,737.1$ & 0.467 & 0.329 & $(67,315.90)$ & $(47,424)$ \\
\hline 5 & $3,291,647.7$ & $2,929,066.24$ & $(362,581.6)$ & $1,270,576$ & $1,130,619.6$ & 0.386 & 0.250 & $(139,956.5)$ & $(9,072)$ \\
\hline T0TAL & $13,477,475.14$ & $13,315,390.04$ & & $7,619,634.1$ & $7,453,369.1$ & & & $31,116.93$ & $132,678.4$ \\
\hline
\end{tabular}

Table 3. Investment profile for cashew oil production by Soxhlet method

\begin{tabular}{|c|c|c|c|c|c|c|c|c|c|}
\hline Year & Cost $(\mathrm{N})$ & Revenue & $\begin{array}{c}\text { Increm. } \\
\text { Benf. }\end{array}$ & Disc. cost & Disc.benf. & $\begin{array}{c}21 \% \\
\text { factor }\end{array}$ & $\begin{array}{c}32 \% \\
\text { factor }\end{array}$ & NPV (21\%) & $\begin{array}{c}\text { NPV } \\
(32 \%)\end{array}$ \\
\hline 0 & 32,000 & - & $(32,000)$ & 32,000 & $(32,000)$ & 1 & 1 & $(32,000)$ & $(32,000)$ \\
\hline 1 & $2,077,026$ & $2,409,750$ & 322724 & 1715632.5 & 1990453.5 & 0.826 & 0.758 & 274,830 & 252,205 \\
\hline 2 & $2,330,423.2$ & 2530237.5 & 199814.3 & 1591679 & 1728152.2 & 0.683 & 0.574 & 136473.2 & 114693 \\
\hline 3 & $2,614,734.8$ & 2656749.4 & 42014.6 & 1474710.4 & 1498406.7 & 0.564 & 0.435 & 23696.23 & 18276.4 \\
\hline 4 & $2,933,732.4$ & 2789586.9 & $(144145.54)$ & 1370053 & 1302737.1 & 0.467 & 0.329 & $(67315.96)$ & $(47424)$ \\
\hline 5 & $3,291,647.7$ & 2929066.24 & $(362581.55)$ & 1270576 & 1130619.6 & 0.386 & 0.250 & $(139956.5)$ & 9072 \\
\hline T0TAL & $13,312,475.14$ & 13315390.04 & & $7,454,650.9$ & $7,618,369.1$ & & & 227,727 & 328678 \\
\hline
\end{tabular}

Table 4. Investment profile for cashew oil production by aqueous method

\begin{tabular}{|c|c|c|c|c|c|c|c|c|c|}
\hline Year & Cost $(\mathrm{N})$ & Revenue & $\begin{array}{c}\text { Increm. } \\
\text { Benf. }\end{array}$ & Disc. cost & Disc.benf. & $\begin{array}{c}21 \% \\
\text { factor }\end{array}$ & $\begin{array}{c}32 \% \\
\text { factor }\end{array}$ & $\begin{array}{c}\text { NPV } \\
(21 \%)\end{array}$ & NPV (32\%) \\
\hline 0 & 32,000 & - & $(32,000)$ & 32,000 & $(32,000)$ & 1 & 1 & $(32,000)$ & $(32,000)$ \\
\hline 1 & 2079066 & 2409750 & 330684 & 1717308.5 & 1575932.0 & 0.826 & 0.758 & 271415 & 250658.47 \\
\hline 2 & 2332712.1 & 2530237.5 & 197525.4 & 1593242.4 & 1338976.7 & 0.683 & 0.574 & 134909.8 & 113379.6 \\
\hline 3 & 2617302.9 & 2656749.4 & 39446.5 & 1476158.4 & 1138526.8 & 0.564 & 0.435 & 2225.8 & 17159.2 \\
\hline 4 & 2936613.9 & 2789586.9 & $(147027)$ & 4308012.6 & 966145.9 & 0.467 & 0.329 & 68661.6 & 48371.9 \\
\hline 5 & 3294880.8 & 2929066.3 & $(365814.6)$ & 1271823.9 & 823720.2 & 0.386 & 0250 & 141204.4 & 91453.7 \\
\hline TOTAL & 13292575.7 & 13315390.04 & & $10,398,545.8$ & $5,811,301.6$ & & & 168414.6 & 209372 \\
\hline
\end{tabular}

$\mathrm{BCR}=1.0017$

$\mathrm{IRR}=25.9$

\subsection{Investment Profile of Production Processes}

\subsubsection{Mechanical Method}

The benefit cost analysis of this method for cashew oil production for a five year period is shown in table 2.The results indicate a positive NPV at both low and high interest rates of 21 and $32 \%$ respectively. At $21 \%$ interest rate, the NPV value is N31, 116.93 while it is N132, 678.4 at $32 \%$. A benefit cost ratio (BCR) of 0.98 which is less than unity was obtained. The result therefore shows that cashew oil production from this method is viable since the BCR is near unity and the internal rate of return is positive at 23.03 percent.

\subsubsection{Soxhlet Method}

From table 3, the calculated NPV is positive with a value of $\mathrm{N} 227,727$ at $21 \%$ discount factor and $\mathrm{N} 328,678$ at $32 \%$ discount factor. This value is higher than what was obtained in the mechanical method. However, the benefit cost ratio is unity which is also higher than that obtained for the mechanical method (0.98), while the IRR is positive at 25.49 percent. The implication of this is that soxhlet method of producing cashew oil is more viable than the mechanical method.

\subsubsection{Aqeoueos Method}

For this method of producing oil from cashew kernel, it is obvious that the NPV value is positive and is estimated to be $\mathrm{N} 168,414.6$ at $21 \%$ and $\mathrm{N} 209,372.2$ at $32 \%$ discount factors respectively (table 4) while the BCR is also unity and an IRR value of 25.9 percent which is higher than that obtained for soxhlet method.

\section{Conclusions}

Results from this study revealed that oils obtained from soxhlet and aqueous methods of expression conforms well with recommended value for edible oil by virtue of their physico-chemical characteristics, and thus should be employed by the would-be oil processor. The investment profile of the production processes also lends credence to the viability of the soxhlet method. 


\section{REFERENCES}

[1] Tonzig S. (1979). Element di Botanica. Vol. 2 Casa Editrice Ambrosiana, Milamo, PP. 1275.

[2] Roth (1974). Desarrolloy estructura anatomica del merey (Anacardium occidentale), Acta Botany Veneguela, 197 233.

[3] Copeland HF (1961). Observation on the reproduction structures of Anacardium Occidentale; Phytomorphology 11, $315-325$.

[4] Pillai CKS (1991). Journal of Applied Polymer. Science. 54, 429-438.

[5] Ojeh O (1985). Cashew kernel - Another locally available source of vegetable oil Nigerian Agricultural Journal. 19/20: 50-56.

[6] Frazatti-Gallina, N.M., R.L. Paoli, R.M. Moura-Fuches, S.C. Jorge and C.A. Pereira, (2001). Higher production of rabies virus in serum-free medium cell cultures on microcarriers. Journal of Biotechnology, 92: 67-72.
[7] AOAC (1970). Official Methods of Analysis $11^{\text {th }}$ Ed. Association of Official Analytical Chemist Washington D. C.

[8] Fellows, P. and Hampton, A. (1992): Small scale food processing. A guild to appropriate equipment. IT publications, CTA, 1992.

[9] Josyln BJF (1976). Methods in Food Analysis. 2nd edn. Academic Press New York San Francisco.

[10] Gotsch N, Burner K (2001).Dynamic supply response and welfare effects of technological changes on perennial crops: The case of cocoa in Malaysia. American Journal of Agricultural Economics. 83(2): 272-285.

[11] Ovy E and Adaiv A. (1976): The production of protein foods and concentrates from oil seed. G. 31, P. 6. Tropical Products Institute, Ministry of Overseas Development, London.

[12] Yahaya LE (1998). Preliminary Study of Gelation Phenomenon in Alkyd Resin Synthesis. M.Sc. Thesis. University of Benin, Benin City, Nigeria.

[13] Gittinger JP (1989). Economic Analysis of Agricultural projects. The John Hopkins University press, London. pp 299-362.

[14] Malindru SN (1977).'Futurism and the cashew tree' Indian Chemical Journal, 19-26. 